\title{
Zinc as diagnostic marker of cancers
}

\author{
Katarzyna Kaczmarek ${ }^{1 *}$, Magdalena Muszyńska², Katarzyna Jaworska-Bieniek', Wojciech Marciniak², \\ Grzegorz Sukiennicki ${ }^{1}$, Marcin Lener ${ }^{1}$, Katarzyna Durda ${ }^{1}$, Tomasz Gromowski ${ }^{1}$, Tomasz Huzarski ${ }^{1}$, Tomasz Byrski ${ }^{1}$,

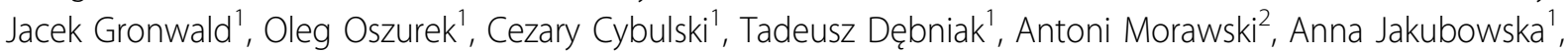 \\ Jan Lubiński ${ }^{1,2}$
}

From Annual Conference on Hereditary Cancers 2014

Szczecin, Poland. 25-26 September 2014

\section{Background}

Zinc is a micronutrient which is essential for human health, playing a role as a cofactor of enzymes such as dehydrogenases, peptidases and component of zinc finger domains. In organism zinc is involved in metabolic pathways, immune processes, maintaining ion balance between other elements. Recently, it has been reported that zinc may play role in chemoprevention, and its level may be associated with occurrence of cancers.

\section{Aim of the study}

The aim of the study was to evaluate a possible correlation between serum $\mathrm{Zn}$ level and occurrence of prostate, colorectal and laryngeal cancers. This will allow to determine whether serum $\mathrm{Zn}$ level may be used as an indicator which patients should be subjected for further cancer diagnostics.

\section{Material and methods}

The study has been conducted in 3 groups: 197 prostate cancer cases and 197 controls, 101 colorectal cancer cases and 101 controls, 109 laryngeal cancer cases and 109 controls.

Zinc level in serum was measured in all individuals by inductively coupled plasma mass spectrometry (ICP-MS) using Elan DRC-e ICP-Mass Spectrometer, Perkin Elmer.

After obtaining results from mass spectrometry, individuals in each group were divided into 4 quartiles. Comparison of number of cases and controls was performed in each quartile. Risk of cancer occurrence was evaluated with regards to the reference category - the lowest zinc level.

\footnotetext{
* Correspondence: katarzyna.kaczm@gmail.com

'Department of Genetics and Pathology, International Hereditary Cancer

Center, Pomeranian Medical University, Szczecin, Poland

Full list of author information is available at the end of the article
}

\section{Results}

We have observed that high serum Zn level $(>991 \mu \mathrm{g} / \mathrm{l})$ was associated with higher incidence of prostate cancers $(\mathrm{OR}=2.43 ; \mathrm{p}<0.003 ; \mathrm{CI} 1.370$ - 4.309). In contrast, high level of $\mathrm{Zn}(>959 \mu \mathrm{g} / \mathrm{l})$ was associated with decreased incidence of laryngeal cancers $(O R=0.08 ; p<0.0001$; CI 0.03122 - 0.1918). In group of colorectal cancers we have not found any correlation between $\mathrm{Zn}$ level and cancer occurrence.

\section{Conclusions}

Results of our study suggest that high level of Zn may be an indicator for prostate examination (ex. PSA, biopsy) and low level of $\mathrm{Zn}$ may be an indicator for laryngeal examination. Serum $\mathrm{Zn}$ level assessment may improve cancer screening by suggesting which patients should be subjected for further testing. Such procedure may increase early detection of cancer. Our results seem to be promising and the study will be also conducted in groups of breast and lung cancers.

\section{Acknowledgements}

This work was financially supported by National Science Centre grant no. 2012/07/N/NZ4/02433.

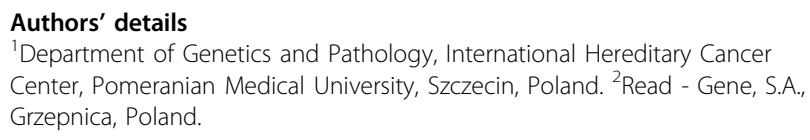

'Department of Genetics and Pathology, International Hereditary Cancer Center, Pomeranian Medical University, Szczecin, Poland. ${ }^{2}$ Read - Gene, S.A., Grzepnica, Poland.

Published: 26 November 2015

doi:10.1186/1897-4287-13-S2-A4

Cite this article as: Kaczmarek et al.: Zinc as diagnostic marker of cancers. Hereditary Cancer in Clinical Practice 2015 13(Suppl 2):A4.
() Biomed Central

(c) 2015 Kaczmarek et al. This is an Open Access article distributed under the terms of the Creative Commons Attribution License (http://creativecommons.org/licenses/by/4.0), which permits unrestricted use, distribution, and reproduction in any medium, provided the original work is properly cited. The Creative Commons Public Domain Dedication waiver (http://creativecommons.org/ publicdomain/zero/1.0/) applies to the data made available in this article, unless otherwise stated. 